\title{
Key Stakeholders' Attitudes in ESP Courses on the Right Teachers
}

\section{Seyyed Hossein Mousavi}

Urmia University, Urmia, Iran, mhossei@gmail.com

\section{Javad Gholami}

Corresponding author, Department of English, Faculty of Humanities, Urmia University, Urmia, Iran, j.gholami@urmia.ac.ir \& gholamij@gmail.com

\section{Mehdi Sarkhosh}

Department of English, Faculty of Humanities, Urmia University, Urmia, Iran, mdsarkhosh@gmail.com

The important question of who should teach ESP courses has been a controversial issue for long. The present study aimed at exploring 300 ESP university students' points of view, $60 \mathrm{EFL}$ and field specialist ESP teachers' perceptions towards the most entitled agents to deliver ESP courses in Iran: field specialists or EFL teachers. To this end, the opinions of the participants who were sampled from three key Iranian universities were investigated through questionnaires and interviews. The results of the questionnaire revealed that there is not a significant difference in the perceptions of ESP students regarding the advantage of one group of teachers (field specialists or EFL teachers) over the other on teaching ESP courses, but they asserted that EFL teachers could be the right teachers for ESP instruction providing that they receive prior training. Furthermore, the results of the interviews from the two groups of teachers indicated that both language and field specialists preferred ESP courses to be collaboratively taught by both EFL and field specialist teachers in order to improve the students' knowledge and motivation for learning. Findings have implications for policymakers and teachers of ESP.

Keywords: attitude, EFL teachers, ESP courses, Field specialists, teaching

\section{INTRODUCTION}

English is by far the most dominant and palatable language of scientific and scholarly conferences, workshops and debates. Strevens (1979) believed that there are two principles in the recent developments in teaching English. The principles focus on the learner's specific needs and try to increase the learner's communicative ability to function in authentic discourse situations. Hence, instruction in the big field of English for Specific Purposes (ESP) has rooted from these two basic principles in academic

Citation: Mousavi, S. H., Gholami, J., \& Sarkhosh, M. (2019). Key Stakeholders' Attitudes in ESP Courses on the Right Teachers. International Journal of Instruction, 12(1), 1041-1058. https://doi.org/10.29333/iji.2019.12167a 
context. As a matter of fact, no one can deny the fact that for the past few decades, there has been a growing need to use English for the articulation of messages within specific professional fields. It is a fact that English teaching is obviously subject to developmental trends, and the main trends of recent years have been that of English for Specific Purposes (ESP). Nowadays, the number of tertiary content departments offering English-medium programs is rising in countries where English is primarily taught as a foreign language as well (Evans \& Morrison, 2011; Wächter \& Maiworm, 2008). In response to this need, the teaching of ESP has turned into a major issue mainly in the contexts where English is taught as a foreign language (Gatehouse, 2001). An issue frequently raised with regard to ESP teachers is whether they need to be experts in the subject area in question. The general assumption is that they are primarily language teachers engaged in Teaching English as a Foreign Language (TEFL) and should, above all, be experts in the language and language teaching, and are not required to have specialized subject knowledge. Nevertheless, they do need to have some understanding of the subject area, which is ideally accompanied with a positive attitude towards it (Hutchinson \& Waters, 1987). ESP teachers should also have the ability to actively integrate student knowledge about the subject matter or, as Ellis and Johnson (1994, p. 26) put it, "it is the learners who have the specific content knowledge and who are able to bring that knowledge to the classroom". Good ESP teachers will thus above all be "experts in presenting and explaining the language," who also have the ability "to ask the right questions and make good use of the answers" (Ellis \& Johnson, 1994, p. 26). In order to deal with this controversial issue, this study tries to find out whose teaching satisfies the students more: EFL teachers or field specialists. Key stakeholders' attitudes are used to assess teachers' teaching effectiveness as well as students' satisfaction of their teachers' teachings.

\section{LITERATURE REVIEW}

Early 1960's is a period in which the zeal for increasing specification of content in English teaching curricula grew tremendously. As with most developments in human activities, English as a Specific Purpose (ESP), in the beginning, was not a coherent, planned movement, but rather was a response to a volatile market. It came out as a particular subcategory of the general task of teaching English to speakers of other languages. Its emergence was motivated by the requirements of the time. It was a socioeconomic phenomenon that sourced from a number of converging trends (Hutchinson \& Waters, 1992). Certainly, a great deal about the origins of ESP could be written. Notably, there are three reasons common to the emergence of all ESP: the demands of a Brave New World, a revolution in linguistics, and focus on the learner (Hutchinson \& Waters, 1987).

Widdowson (1983) recognizes two reasons for the development of ESP into a separate institution: one is the changing pattern of requirements for English in the emerging Third World and the other is the coincident interest in language registers arising mainly out of the work of Halliday and his associates in Edinburgh. It seems that ESP now is a widespread area and lots of students throughout the globe are learning ESP in order to increase their professional ability and get a job and career adaptable to their own 
psychological characteristics and abilities. For this reason, various factors such as authentic texts related to ESP learners' ability and qualified teachers can assist the learners to expand their knowledge of English and texts in English. According to Belcher (2009, as cited in Lafford, 2012), ESP designers are committed to important processes that are prerequisites for operationalization of ESP. These processes are as follows:

1) Exploring students' needs (before, during, and even after instruction) as a first and foremost necessity, 2) developing or adapting materials and methods to enable needsresponsive instruction, and 3) acquiring the expertise to function as needs knowledgeable instructors. Since the early 1960's, ESP has been a widespread branch of English as a foreign language (EFL) instruction in Iran. Similar to various countries, the position of teaching ESP has been on the edge in Iranian tertiary education (Atai, 2000, 2002; Atai \& Tahririan, 2003). Most significantly, the content, methodology, classroom techniques and activities which are looking forward to stress the expansion of reading professions appear to attract the trainees to translate some texts from English to Persian. Co-texts and such tools as graphs, diagrams, and semantic maps are not involved in ESP textbooks (Faharzadeh, 2000; Mazdayasna, 2008; Mazdayasna \& Tahririan, 2008).

Regardless of the theoretical examination of ESP courses, there are some studies in the context of Iran as an EFL context that take into account the ESP from practical point of views. For instance, more recently, Aliyasin and Pouyan (2014) tried to search the Iranian university students' opinions about the rather argumentative question of who should train ESP courses among EFL instructors and the experts-in-the-field in Iran. The outcomes demonstrated that the students' rank of satisfaction with the EFL instructor was considerably greater than that with the expert-in-the-field one. Kazemi and Ashrafi (2014) attempted to inspect in-service training schedules to distinguish if they achieve the purposes framed for them in the first step. The qualitative and quantitative data analysis raised significant worries about the sufficiency of the schedules and expressed that they fell short of performing the purposes planned for them.

There are various communities involved in ESP, from students to EFL teachers, field specialist teachers, ESP course instructors, board of editors, researchers from top-tier ESP/EAP journals, reviewers, chancellors of universities, deans of faculties and heads of departments all of whom play a role whether direct or indirect in running and channeling the courses. Some of these partners benefit or lose directly from ESP courses like teachers and students, some others possess the cutting-edge knowledge such as researchers, reviewers or board of editors who strongly favor fruitful and beneficial course outcomes, they are theoretical proponents of the camp who hold unbiased, neutral and non-judgmental views about the issue at hand, others as policy-makers at university, ministerial or even national level compose the indirect partners of the ESP game. The afore-mentioned sectors of ESP as key-stakeholders of the camp are going to provide their own attitudes and voices regarding the most eligible and entitled teachers who should teach ESP courses in Iran.

As a matter of fact, individuals who are involved in the process of ESP are considered as stakeholders and their points of view regarding ESP need to be explored. Although there 
are some studies in the field of ESP that focus the attitudes of key-stakeholders individually in various studies, actually there is no study that touches their attitudes holistically in a comprehensive study. As a result of the paucity of research on this issue, we still find that there is a lot of conflicting controversy on this issue in which the jury is still out in the Iranian context, especially at the level of policy making. Henceforth, the exploration of key-stakeholders' ideas could be really eye-opening and insightful at Iran's English success at the university level. Therefore, an attempt was made to seek the answer to the following research questions:

RQ 1. What attitudes do university students with field specialist ESP teachers and students with EFL teachers hold toward the most entitled practitioners of ESP courses at universities?

RQ2. Is there any significant difference in the attitudes of university students with field specialist ESP teachers and students with EFL teachers toward the most entitled practitioners of ESP courses at universities?

RQ3. What attitudes do ESP-teacher/non-ESP teacher filed specialists and EFL teachers hold toward the most entitled practitioners of ESP courses at universities?

\section{METHOD}

For ESP research to better play this supportive and pragmatic role, it will need to extend its trajectory of both broadening and deepening the understanding of communicative practices or discourses, communities of practice and learners (Belcher, 2012). For this reason, combining both macro and micro-analytic approaches can be equally useful.

\section{Design of the study}

The design of the present study is predominantly a qualitative study in nature and was aimed to be conducted through triangulation, that is, several methods of data collection such as observation, questionnaire and interview were implemented.

\section{Participants}

In order to investigate ESP students' attitudes or perceptions regarding who is the most entitled teacher (ESP teachers or field specialists), a total number of 300 ESP students learning English as technical English in different universities like Islamic Azad University, Tabriz Branch, University of Tabriz, Payam Noor University of Tabriz, Urmia University, Islamic Azad University, Urmia Branch, and Payam Noor University of Urmia were selected randomly. The participants' age range was 19 to 38. All of them spoke Persian as their official language and were taking English for Specific Purposes courses in their respective majors such as computer engineering, Physics, MBA, and so on.

In addition, a total number of 30 instructors (15 field specialists and 15 ESP instructors) participated in this study. The instructors were selected from among the ones teaching hard sciences (e.g., engineering, medical sciences, etc.) as well as teachers teaching soft sciences in those universities. Random selection as a subcategory of probability 
sampling was the criterion for choosing 30 instructors. Besides, the ESP instructors participated in the study with the same aim of identifying the right teachers. Face to face interviews or questionnaires were the tool for their data collection.

\section{Data collection instruments}

Different instruments were used in this study in order to answer the research questions. The first instrument was a 30-item researcher-made questionnaire revolving around the similarities, differences, merits and demerits of field specialists and ESP teachers. It is worth mentioning that the questionnaire was piloted with 30 of the ESP learners before the onset of the study. After this phase, the validity of the designed questionnaire was confirmed by three experts in Applied Linguistics through expert-validation. The internal reliability was calculated through Cronbach's Alpha method, and the reliability of the questionnaire was found to be 0.84 (See Appendix for a sample copy of ESP students' questionnaire). The students expressed their points of views by simply choosing one of the responses on a four-point scale anchored with the notations: "Strongly agree, agree, disagree, and strongly disagree." Due to their low-level of English, the researcher decided to design the scale in Persian.

The second instrument was a semi-structured interview in which field specialists and ESP teachers were asked questions of various types regarding those who should take the responsibility of teaching ESP courses to ESP learners in various majors. Since the study was an attempt to explore the attitude of instructors and university students regarding who is the right teacher in ESP field, hence, the researchers designed a general question in interview to probe the topic. Moreover, a similar semi-structured interview like that of the instructors' was administered to $10 \%$ or about 30 of ESP learners in order to elicit those participants' attitudes directly. It was conducted in order to obtain deeper and more detailed insights into the themes of the questionnaire. As it is axiomatic, questionnaire by its nature suffers from validity problem since its validity depends on the honesty and cooperation of the participants, since questionnaires are structured instruments, they allow little flexibility to the respondent with respect to response format (Dorniye, 2005). In essence, they often lack some extra responses that the participants want to produce. Or when questionnaires arrive in the mail, it is natural to assume that the respondent is the same person you sent the questionnaire to. This can be a disadvantage for the instrument (Dorniye, 2005). This made the researcher to employ interview as an extra data elicitation tool to compensate for the limitations of the questionnaire.

\section{Procedure}

The required data for this study were gathered during the academic year 2016-2017. The researcher-made questionnaires were primarily piloted with a group of 30 ESP students before distributing the questionnaires to 300 ESP learners. There upon, they were encouraged to raise questions if they faced any problems understanding the statements to be provided with feedback. Fortunately, there was no item that caused ambiguity for the students. Having considered the piloting of the questionnaire, the researcher 
distributed the scale among the ESP students manually and described the study to the respondents to explore the learners' perceptions about the most righteous teachers.

A semi-structured interview was designed by the researcher and presented to $10 \%$ of the learners in order to investigate their beliefs about who should teach ESP course. The same interview was conducted with ESP teachers and field specialist, and subsequently their beliefs were gathered.

As Dornyei (2003) stated, data analysis is the most complex and mysterious of all the phases of a qualitative project and in order to generate findings that transform raw data into new knowledge, a qualitative researcher must be engaged in active and demanding analytic processes throughout all phases of the research (Thorne, 2000). Since the current study also was qualitative in nature, the researcher used a thick description of transcriptions of semi-structured interviews during data analysis phase. The interviews were in Persian but the transcriptions were designed in English, for this reason, the researcher emailed the transcriptions of the interviews to the teachers under study and asked them to verify the transcription; the verified transcriptions were returned via email.

In order to investigate the attitudes of university students with field specialist ESP teachers and students with EFL teachers toward the most entitled practitioners of ESP courses at universities, different types of statistical analyses were run. Descriptive statistics containing mean, standard deviation, and standard error of the mean are more common to summarize the data and inferential statistics were applied in order to generalize the data. Given the nature of the variables and design of the study, correlational analyses were run. As the second step, the results of the interviews from the teachers and ESP students were discussed in the qualitative data analysis section in order to explore the most qualified agents to run ESP courses.

\section{FINDINGS}

To deeply investigate the students' intentions, an unstructured interview was administrated to explore the main question of "who is more eligible to teach ESP courses, EFL teachers or field specialists?" This question was the focus of the first research question. The following extracts from the university students under the study can give a clearer view.

\section{Extract 1: university student with EFL teacher:}

"I think, an EFL teacher who knows the field under study is for sure better than a field specialist, but there is no such a teacher."

Looking critically to the first part of this extract, we can suppose that perhaps the student has some type of bias or prejudice to his EFL teacher, but the assumption can be rejected by looking at the second part when he states "but there is no such a teacher."

Extract 2: university student with a field specialist: 
"Our teacher brings an article in English to the class, we read, translate it and take our notes. That's all we do in the technical English classes.... A total of 10 or 15 pages we work each term and the students do not learn anything."

This student mentions the drawbacks of field specialists and their mechanical roles in ESP courses that can be considered as translators rather than ESP teachers. DudleyEvans and St. John (1998) prefer the term "ESP practitioner" as this definition seems to be more detailed and complete. They distinguish different key roles of ESP practitioner such as teacher, course designer and materials provider, collaborator, researcher and evaluator. Hence, based on the above-mentioned words, the sensitive and touchy role of teachers (no difference whether they are EFL teacher or field specialist) in ESP courses can be clearly felt.

\section{Extract 3: university student with EFL teacher:}

"You know what, the problem should have been solved in elementary levels, I mean English should start at early ages so that the students do not have general English problem. Students in universities have phobia in English because the lack the knowledge of its ABC's. This problem is even more visible about the students coming from suburban areas, no quality language schools and teachers and Ministry of Education is unsuccessful in this regard... We lack the background knowledge to attend technical English course. The course is a very boring and useless waste of time."

Again, this extract has a critical point of view not to the teachers in particular but to the Ministry of education in Iran. In fact, the student alertly pays special attention to the lack of a comprehensive program in the Ministry of Education that expands and reinforces demotivation in learning English as an international language. From the ideological point of view, society and major policy makers surely affect some anomalies in the Ministry of Education that subsequently cause dissatisfactions.

\section{Extract 4: university student with a field specialist:}

"If our General English is at an optimal level, then we would learn better. The teacher reads the book and translates it. The pronunciation is zero. Sometimes we skip some parts of the text because even the teacher does not understand its meaning. His English is funny and he teaches the same lines each term."

Lack of good and masterly pronunciation, the monotonous nature of the semesters and the unfamiliarity with the meaning of some words except specific words show the incapability of field specialist based on one of his/her students' attitude. Students' statements in extracts 5 and 6 praise EFL teachers as the best choices in ESP courses, whereas in extract 7, the university teacher, once an ESP student, believes that an EFL teacher cannot be a good ESP teacher even if he/she has completed the education abroad. The extracts clarify the explanations.

\section{Extract 5: university student with EFL teacher:}

"One who has background in the field of study and English is better to teach these courses. EFL teachers have the experience and expertise enough to deal with the needs 
of students. The communication bridge they create between students is exemplar and of utmost importance. They are educated and trained to do so. It is through these hidden techniques that they relay the complexities of grammar, jargon to the students. Their teaching is not through suppressing students to learn some tough, decontextualized words by an outdated and obsolete translation practice." (With an expression of sarcasm towards field specialist and their common practices)

\section{Extract 6: university student with both field specialist and EFL teacher}

"The courses, in our university, are generally taught by field specialists, I myself, however, had the experience of studying with both EFL and field specialist. Both were excellent. My teachers both studied abroad and the courses were useful...."

Extract 7: university student with a field specialist (in Physics, talked of his experiences as a student and now a professor):

"Physics professors taught the courses, they were not useful at all. They did not focus on grammar. In fact, they were mere translation courses. They chose one article in the field and told us to translate it into Persian and bring it. The instructor even had studied abroad, however, it was not useful at all. We had some EFL teachers teaching courses and they had extreme problems in the field related materials. They should assign EFL teachers for each department and they promote their experiences to teach the courses. One EFL teacher can never teach in every specific field.... since EFL teachers nowadays teach in various fields, they are mostly teaching general rather than specific English which creates some challenges."

\section{Extract 8: university student with a field specialist:}

"As a student, we studied with a field specialist graduated from a foreign country. The courses were both fruitful and informative, however, this does not mean that they (EFL teachers) cannot teach well. As an example, an EFL teacher naming... taught the course and he was really experienced in doing the course, even he corrected course translator's error when he mistakenly translated daily/dairy interchangeably...".

As it is clear, from the findings, almost all of the university students have the threshold level problem in ESP courses. A favourable teacher is frequently referred to as someone with both the knowledge of language and the content. Field specialists who teach the majority of mentioned courses teach vocabulary decontextualized, translation-centred with funny pronunciations which ultimately does not prepare the students to do the criterion tasks in real life situations. On the other hand, EFL teachers analyse students' needs well, know teaching methodologies and are better at connecting with the students, although sometimes they lack knowledge of specific terms and words. Their problem, however, lies in their illiteracy in the content they are teaching.

In order to explore the difference in the attitudes of two groups of university students (those with field specialist teachers and those with EFL teachers) toward the most entitled practitioners of ESP courses at universities, the questionnaires were analysed. The results of descriptive statistics of the scores are represented in Table 1. 
Table 1

Descriptive statistics of the questionnaires

\begin{tabular}{llllll}
\hline & $\mathrm{N}$ & Minimum & Maximum & Mean & Std. Deviation \\
\hline $\begin{array}{l}\text { Students with EFL } \\
\text { teachers }\end{array}$ & 150 & 69.00 & 101.00 & 82.9467 & 7.39471 \\
\hline $\begin{array}{l}\text { Students with Field } \\
\text { Specialists }\end{array}$ & 150 & 48.00 & 80.00 & 64.9333 & 9.48943 \\
\hline Valid N (listwise) & 150 & & & & \\
\hline
\end{tabular}

As the table shows, the mean of the first group or EFL teachers is 82.9 and the mean of the second group or students with field specialists is 64.9. Then, it can be concluded that the scores of the first group are higher than those of the second group, but this is not enough for the final conclusion, then before running correlational analysis, there is a need for running normality test. To test the normality of the scores, One-Sample Kolmogorov-Smirnov test was run. The results showed that the data were not normallydistributed, hence instead of Pearson correlation, Spearman's rho was used.

Table 2

Nonparametric correlation of the scores

\begin{tabular}{lllll}
\hline & & & EFL & Field Specialists \\
\hline \multirow{3}{*}{$\begin{array}{l}\text { Spearman's } \\
\text { rho }\end{array}$} & EFL & Correlation Coefficient & 1.000 & -.047 \\
\cline { 3 - 5 } & & Sig. (2-tailed) & - & .571 \\
\cline { 2 - 4 } & & $\mathrm{N}$ & 150 & 150 \\
\cline { 2 - 5 } & \multirow{2}{*}{$\begin{array}{l}\text { Field } \\
\text { Specialists }\end{array}$} & Correlation Coefficient & -.047 & 1.000 \\
\cline { 3 - 5 } & & Sig. (2-tailed) & .571 & - \\
\cline { 2 - 4 } & $\mathrm{N}$ & 150 & 150 \\
\hline
\end{tabular}

Based on the analysis, there is a negative correlation between the variables of the study at 0.047 . However, the correlation coefficient is not significant because the sig. value $(0.571)$ is more than $\mathrm{p}$ value $(0.05)$. Then, it can be concluded that there was no significant relationship between university students with field specialist ESP teachers and those with EFL teachers toward the most entitled practitioners of ESP courses at universities.

As already mentioned, the perceptions of ESP filed specialists and EFL teachers were the other focus of the study. To explore the attitudes that ESP-teacher/non-ESP teacher filed specialists and EFL teachers hold toward the most entitled practitioners of ESP courses at universities, the researcher used a semi-structured interview that has been designed to gather the information from six instructors (of the total 30) about teachers' beliefs about who should teach ESP. The following extracts are taken from teachers' perceptions after recording and transcribing the data.

Extract 9 (ESP field specialist, 10 years of experience):

I never say that field specialist is more qualified to teach ESP or the EFL teachers. I say that we need EFL teachers on one hand in the ESP courses because they are more familiar with the teaching rules and methods such as how to teach a new word or grammar and how to deal with the students as different individuals from the emotional, 
cognitive and personal point of view. Also, we need content teachers on the other hand since they know how to teach the content of a major such as medicine because they have the knowledge of the course as are involved with the course for years.

\section{Extract 10 (EFL teacher, 6 years of experience):}

Students see the teachers as transmitters of knowledge about the course. Also, they like to be dealt with them as human-beings and be respected as individuals. These two aspects can be given to the students by two groups of the teachers, I mean both ESP teachers and content teachers can work in cooperation with each other during the courses, for instance, at BA level EFL teachers can motivate the students to learn the content through English and at MA or higher levels, field specialists can transfer the knowledge of the content.

\section{Extract 11 (ESP field specialist, 8 years of experience):}

As a matter of fact, if there were content teachers who were professional in English, it was wonderful. However, this situation is very difficult in a country like Iran where exposure to English is very limited. As a result, the Ministry of Higher Education should provide the atmosphere where both groups of teachers cooperate with each other to train ESP students skilfully.

\section{Extract 12 (EFL teacher, 10 years of teaching):}

"In my idea, EFL teachers should teach the course but the course can be more successful if the universities provide us with some sort of training courses prior to the administration of the class or let both teachers be present at the classes and help the students to learn the content with the advantages coming from both groups. For example, EFL teacher can manoeuvre on the language and at the same time, field specialists teach the content to the students."

\section{Extract 13 (field specialist, 15 years of experience):}

Although the content of the course is important, teachers should gain the knowledge of how to teach the course, how to create opportunities to involve all the students in the process of teaching, and how to respect the students based on their emotions which is very important because we deal with human-beings rather than machines. Personally, I think none of them.... ESP courses do not give out any results. They are a waste of time and budget. They are excuses for filling of the units in order to complete a degree in universities. When the students have no general English base, what can the meaning of holding ESP courses be? It is totally futile effort."

The overall atmosphere among both teachers talks of a dominant disappointment with such courses. Both regard it a loss of time and budget. Field specialists teach the majority of classes. In some universities, it is rare to find classes taught by EFL teachers such as Tabriz and Azad universities. As the results of the interview revealed, no party is seen as fully qualified course teacher, each party has its own strengths and drawbacks. Almost all of the teachers tended to work cooperatively to run classes in an optimal manner with EFL teachers exploring humanistic, methodological and linguistic aspects and content teachers working on the field specificities. Some EFL teachers favour 
training courses prior to their teaching in such courses. Both teachers favour a sort of bridge to be created either by decision-makers of the Ministry or by English Departments and various faculties in the universities as is successfully experienced by some universities such as Shiraz University of Medical Sciences and Iran University of Medical Sciences.

As already-mentioned, in addition to exploring university ESP students and their instructors' (EFL teachers and ESP field specialists) points of views, this study aimed at exploring key-stakeholders' attitudes and preferences on the right instructors for ESP courses through eliciting the attitudes of the key-stakeholders, namely policy makers including university officials (chancellors, deans, heads) as well as key scholars and scientists in ESP/EAP. The results of semi-structured interview have been classified into the following five major questions as follow. The answers coming from the individuals, as indirect stakeholders as well as the ones who possess the cutting-edge knowledge with unbiased, neutral and non-judgmental views about the issue at hand. These points of views could surely be really eye-opening and insightful for the triangulation of the findings in this study. The questions and the gist of the answers were as follows:

1. Between field specialists in their respective disciplines and EFL teachers with MA or $\mathrm{PhD}$ degrees in TESOL/TEFL/Applied Linguistics, in your view, who is more entitled to deliver and run ESP courses in an EFL contexts like Iran? Given your expertise in the field, please elaborate on your answer and justify your position. It is difficult to say, but field specialists who have the necessary technical information together with a good command of the language seem to be more eligible to take the courses. In fact, those who have expertise in English cannot teach well other fields' specific courses, because they need to have a thorough understanding. For example, when an EFL teacher wants to teach psychology, he should be able to comprehend cognitivists and behaviourists quite well. It would be great if the EFL teacher has an undergraduate degree in psychology. Another alternative could be some bilateral meetings between field specialists and EFL teachers if they are to teach fruitfully in ESP courses.

2. What strengths and weaknesses (pros and cons) are there for field specialists running these ESP courses? The strength is familiarity with the content and special jargons of the scientific disciplines; the weakness can be insufficient command of the language of instruction which creates problems of misinterpretation, misperceptions and transmission of erroneous information. This flaw can mislead students, even render them disappointed, demotivated and perplexed, in the long run.

3. What strengths and weaknesses (pros and cons) are there for EFL teachers running these ESP courses? Their weakness lies in their unfamiliarity with the content of the specific disciplines and lack of training in the field they are teaching which can have serious ramifications. They simply do not have the faintest clues about some complicated purely scientific concepts and ideas. This condition can undermine their self-efficacy transmitting the same negative feelings of hopelessness and confusion to their students. Their strength is their satisfactory command of the language of instruction which equips with the necessary instrument to explain the scientific concepts once they can grasp the necessary technical knowledge of the discipline. 
4. How could field specialists contribute to the improvement of these courses if EFL teachers are assigned to exclusively run these courses? Joint activities and team-works with effective collaboration can bring about amazing pedagogical outcome. The gaps in special ESP teaching, the linguistic and scientific ones, can be reduced as far as possible in a harmonious fashion. Field specialist can tackle the sophisticated scientific ideas and concepts.

5. How could EFL teachers contribute to the improvement of these courses if field specialists are assigned to exclusively run these courses? EFL teachers can provide them with linguistic information, learning and teaching procedures, textbook characteristics and appropriate assessment methods.

An ESP course instructor, as unbiased and knowledgeable stakeholder, with 20 years of experience claims:

"A physics professor teaching in England does not have the problem of language, he is the owner of that science and a native speaker, and hence he has genre-awareness. Here in Iran, however, the physics professor has neither good English knowledge (i.e. understanding different complexities of language) nor does he have genre-awareness in physics, because it is an imported science. This is where the issue becomes really challenging and it is the time when an EFL teacher should be the person teaching these courses. However, the EFL teacher teaching such courses should have some special qualities. He should be an applied linguist as well as a teacher. He should play different roles such as teacher, applied linguist, evaluator, syllabus designer and other roles as an ideal teacher..... the philosophy of English as a field of study in Iran is to do service to other fields of study so that their students have the ability to read, write, speak and listen well in English. If we are to have a word in today's world, we should revolutionize English knowledge of students in different fields of study.......we also have the problem of threshold general English in Iran. The university students do not have a good general English and when they are attending ESP courses, they actually are attending general English classes instead. They are not ESP courses in nature at all."

The results of all analysed questionnaires echo that no party is seen as fully qualified, each party has its own strengths and drawbacks, which could complement each other as a whole if both camps, like isolated islands, could be linked together. There are effective teachers from both camps teaching in the universities, however, they are exceptional cases who cannot solve the problem in the national scale. The data also pictured EFL teachers in the ... of English Department doing services for various university faculties in different stages of complex process of language teaching and learning. A sense of companionship and cooperation between field specialist and EFL teachers is a requirement if they are to have quality ESP courses. Team teaching or sheltered teaching is another healer suggested by the last group of key-stakeholders.

\section{DISCUSSION}

The aim of this study was to study "who should teach English for Specific Purposes (ESP), field specialists or language teachers teaching in English department of a specific faculty according to their students' perceptions, field specialist teachers' points of view and EFL teachers' attitudes. The main question from the university students tended to 
investigate whether there was a significant difference between the two mentioned groups of instructors based on students' points of views. As mentioned before, the results of the questionnaire revealed that there was no significant difference in the attitudes of two groups of students who were under the instruction of EFL and field specialist teachers. To increase the validity of the study via instrument triangulation and to overcome the questionnaires' drawbacks, a semi-structured interview was conducted to sixty of the students (30 students were taught by EFL teachers and the other 30 students were taught by field specialists) and the results showed that power relations in the society made the university students withdraw their perceptions regarding who should teach ESP courses. The students unanimously believed that EFL teachers are more reasonable to teach ESP courses since they are familiar with the integration of sciences and information such as psychology, method and approach; surely, they will be the most influential ones in teaching ESP courses since they know grammar, language, the manner of transferring the information and they know how to deal with the students as human-beings. They will be more qualified if they increase their knowledge of specific terms before teaching any specialized text, try their best to acquire enough knowledge of its subject-matter.

One justification for these points of view may go to the fact that based on the content of the questionnaire, students pay much more attention to the characteristics of teachers that related to the emotional aspects such as 'respects learners as individuals', 'are friendly towards learners' and 'understands learners well'. Although some items such as 'has a good knowledge of subject matter' and 'has the ability to manage the classroom well' were important to the students of field specialists.

The other focus of the study was on two groups of teachers (subject teachers and EFL teachers). Generally, each group of teachers in the interviews considered themselves as the authorities in ESP teaching and specified their own merits for occupying the place of ESP course, for instance, field specialists perceived themselves as better candidates for teaching these courses because "knowledge about the field can take precedence over knowledge about language learning and teaching" (Anthony, 2011, p. 2), on the other hand, EFL teachers believed that, in all ESP courses, it is the language that must be taught and not a specific subject, and since language teaching is a kind of science and has its own specific knowledge and principles such as teaching methodology, language testing, phonology, sentence and vocabulary structure, grammar, etc., every language teacher must be adequately aware of these basic principles. Their reason for this claim was the fact that in higher academic levels and in the ESP courses to postgraduate students such as the students of medicine, dentistry and so on, the direction should be changed from the teaching of just a number of technical terms and notions to improving the students' linguistic skills such as speaking and writing; and as teaching these skills falls within the scope of language teachers' tasks, these courses therefore can and should be preferably taught by them.

EFL teachers believed that field specialist, even with good mastery in English, most often fail to teach the language well, they just translate the texts. Although translating specific texts and vocabularies as workload is an opportunity for ESP teacher development, enculturation, and integration into content departments (Tatzl, 2013), actually, it can decrease the quality of ESP classrooms. 
The findings of the study also subscribe to Ellis and Johnson's (1994) notion that good ESP teachers are experts in language and language teaching; and they have the ability to ask the right questions and make good use of the answers. The findings also confirm the view that the EFL teacher is in a better position to teach the ESP course than the specialist-in-the-field because the former subscribes more substantially to the traits of an ESP teacher as outlined by Savas (2009). He states that since ESP teaching requires particular and sometimes special skills such as dealing with language input, handling skills work, answering questions on terminology, and listening to lectures and research presentations and seminar skills training, Functional Academic Literacy (FAL) is an inevitable skill for an ESP teacher. As the EFL teacher of ESP has already sufficient control over the target language (English) itself, he can have acquired the FAL more effectively than the specialist-in-the-field instructor (Savas, 2009). Likewise, these findings indicate that the EFL teacher of an ESP course may be said to perform more effectively in the roles of the ESP practitioner (teacher, course designer, researcher, collaborator, evaluator) as designated by Dudley- Evans and St John (1998) than the specialist-in-the-field instructor because the former enjoys the prerequisites for most of these roles more adequately than the latter.

Finally, a comprehensive result obtained from the interviews from both groups of teachers revealed that the teachers preferred the course taught with both field specialists and EFL teachers in order to improve the ESP students' knowledge both from linguistic point of view and from content knowledge. In this respect, Atai and Fatahi-Majd (2014) stated that even though there is no clear vision of the teachers' cognition and implementation while collaborating, actually team teaching between EFL teachers and subject teachers seems to be a viable option to address the drawbacks of ESP courses. The results of the current study were in line with some studies conducted in the context of Iran (Ahmadi, 2007; Aliasin \& Pouyan, 2014; Atai \& Fatahi-Majd, 2014; Maleki, 2006). Very similar to the results of the present study, Aliasin and Pouyan's (2014) study preferred EFL teachers to those of field specialists and their justification was the fact that EFL teachers during their education were exposed to various courses that pay attention to both emotional and cognitive aspects of the students. This type of instruction surely is a merit for EFL teachers.

In contrast to the results of the current study and the above-mentioned one, Ahmadi (2007) believed that field specialists should handle ESP courses since "in teaching of ESP courses at all levels, discipline-specialist teachers with an adequate mastery on English, are more competent than language teachers since they are much more familiar with the technical terms and topics of the students' field of study" (p. 45). The researcher added that the most important aim of ESP courses is to help students understand the specialized texts of their ESP textbooks, and as there are many technical terms, notions and topics in these texts, they should be taught by the teachers of the same specialty and not by language teachers, who are not sufficiently familiar with those terms and topics. It can be clearly understood that the there are some discrepancies in the results, but generally the studies concluded that team teaching and collaborative teaching can be beneficial in ESP courses. 


\section{CONCLUSION}

The primary focus of the study was on exploring the problematic question of "who should teach ESP courses, EFL teachers or field specialists as content instructors?" The study was a comprehensive and comparative one and used triangulation tools such as questionnaires and interviews to obtain the perceptions from two groups of teachers and university students. The results of the questionnaires from 300 university students with EFL and field specialist's instructors revealed there was not a significant difference between the perceptions of two ESP students with different types of teachers regarding who is more qualified to teach ESP course. The in-depth results of interviews from the students represented that even though the students holistically pointed to the EFL teachers as qualified teachers in ESP courses, actually power relations in the society discouraged them from mentioning this point of view freely. Furthermore, it was demonstrated by the results of interview from 30 teachers that both groups of teachers preferred the course taught with both EFL teachers and field specialists in order to improve the ESP students' knowledge both from linguistic point of view and content knowledge.

Like other researches, this study was not without limitation. One of the limitations that seems to decrease the generalizability of the findings can be the ignorance and exclusion of students' English language proficiency level from this research context. The reason behind this decision was the assumption that the students had already been selected via a nation-wide entrance exam and thus they were supposed to be almost at the same level of language proficiency. However, language proficiency variable can be included in further researches by others.

As for implications of this research for material development, it can be stated that material developers can include text books that are related to the words that both teachers want to teach. Then curriculum developers can design textbooks which cover both linguistic features and special vocabularies which help both teachers to try their best in order to increase ESP students' understanding from English language and special words related to the students' majors simultaneously. It is hoped that more research studies will be conducted in order to contribute to understanding ESP issues properly and propose suggestions for the academics, ESP administrators, English language planners, and policy makers.

\section{REFERENCES}

Ahmadi, M. (2007). Who should teach ESP? Retrieved from https://www.tesolrance.org/Documents/Colloque08/ Ahmadi.pdf

Aliyasin, H., \& Pouyan, P. (2014). An investigation into Iranian university students' views about who should teach ESP courses: A specialist-in the field instructor, or an EFL teacher? English Language Teaching, 1 (1), 75-96.

Anthony, L. (2011). Products, processes, and practitioners: A critical look at the importance of specificity in ESP. Taiwan International ESP Journal, 3(2), 1-18. 
Atai, M. R. (2000). ESP revisited: A reappraisal study of discipline-based EAP programs in Iran. Unpublished Ph.D. dissertation, University of Isfahan, Isfahan, Iran.

Atai, M. R. (2002). Iranian EAP programs in practice: A study of key methodological aspects. Sheikhbahaee ELT Journal, 1(2), 1-15.

Atai, M. R., \& Fatahi-Majd, M. (2014). Exploring the practices and cognitions of Iranian ELT instructors and subject teachers in teaching EAP reading comprehension. English for Specific Purposes, 33, 27-38.

Atai, M. R., \& Tahririan, M. H. (2003). Assessment of the ESP status in the current Iranian higher education system. Paper presented at LSP 2000, communication, culture and knowledge, University of Surrey, Guilford, UK.

Dudley-Evans, T., \& St. John, M.J. (1998). Developments in ESP: A multi-disciplinary approach. Cambridge: Cambridge University Press.

Evans, S., \& Morrison, B. (2011). The First Term at University: Implications for EAP. ELT Journal, 65(4), 387-397.

Faharzadeh, M. (2000). Analysing discoursal and formal needs of student of psychology and sociology. Unpublished M.A. thesis, University of Isfahan, Isfahan, Iran.

Gatehouse, K. (2001). Key issues in English for specific purposes (ESP) curriculum development. The Internet TESL Journal, 7 (10).

Hutchinson, T., \& Waters, A. (1987). ESP: a Learning-centred Approach. CUP.

Kazemi, A., \& Ashrafi, M. (2014). In-service training programs for Iranian EFL teachers revisited. International Journal of Asian Social Science, 4(10), 1062-1076.

Lafford, B. (2012). Languages for specific purposes in the United States in a global context: Commentary on Grosse and Voght (1991) revisited. The Modern Language Journal, 96, 1-27.

Mazdayasna, D. (2008). Developing a profile of the ESP needs of Iranian students: The case of students of nursing and midwifery. Unpublished Ph.D. dissertation, University of Isfahan, Isfahan, Iran.

Mazdayasna G, Tahririan, MH (2008). Developing a profile of the ESP needs of Iranian students: The case of students of nursing and midwifery Azad University Yazd, Iran. Sheikhbabaee University, Iran. Retrieved September, 25, 2009 from Www.sciencedirect.com/science/journal/14751585

Strevens, P. (1979). Functional Englishes (ESP). The British Perspective: Mimeo.

Tatzl, D. (2013). Translating and revising as opportunities for ESP teacher development. TESOL Journal, 4(2), 332-344.

Wächter, B., \& Maiworm, F. (2008). English-taught Programs in European Higher Education: The Picture in 2007. Bonn: Lemmens. 
Appendix: Questionnaire on the Right Teachers for English for Specific Purposes courses at university programs

Dear student: The following questionnaire is meant to explore your attitudes on the most entitled ESP teachers (namely, Field Specialists or English Language Teachers) for running and instructing English for Specific Purposes (ESP) and English for Academic Purposes (EAP) courses at university programs. Please read the following items, think about them, and choose the best and most appropriate section which expresses your attitude on the topic in light of your own beliefs and past learning experiences in such courses.

\section{Questionnaire Items}

1) I think that the language knowledge of English teachers helps them to have better classes.

2) The correct pronunciation of a language teacher is the key factor for an ideal language class, and I think that language teachers have this feature.

3) Field specialists have knowledge of technical terminology in their field, that's why they teach these courses better.

4) In my opinion, field specialists know the specific topics so they can transfer the content in the best way possible.

5) There are so many keywords that English teachers do not have any knowledge of these words.

6) In my opinion, one of the main needs of students is translation, and field specialists do this professionally, which is why they are the best teachers to deliver the courses.

7) In my opinion, translation is futile and time-consuming, and that is why language teachers rarely do it.

8) Language teachers have been trained to teach languages, and language courses are not different from general language for special purposes. Therefore, whatever they do in teaching can be used in English courses with special purpose.

9) I think that field specialists cannot teach these courses because they are not trained as language teachers and teaching language is different from teaching physics, chemistry, engineering, etc.

10) I feel I am more motivated to learn a language with a language teacher than a field specialist.

11) Field specialist classes are extremely tedious and monotonous.

12) In language teachers' classes, I also learned some of the language learning methods together with the content of the specific field.

13) Language teachers use a wide range of activities and techniques in their classes, and I'm not tired at all in these classes.

14) Field specialists have one or two activities in their classes and their classes are really boring.

15) The amount of team work and the level of interaction in the classes of language teachers are very high.

16) The amount of team work and the degree of interaction in the field specialist classes are very small.

17) In classes where language teachers teach, if the teacher faces a problem with our specific terms, we can easily come to the aid of the professor, and this will result in better interaction between the teacher and the student. 
18) In my opinion, there is a better democratic atmosphere in the language teachers' classes, because the information flow is not just from the teacher to the student, sometimes it is from the student to the teacher.

19) I do not expect my language teacher to have the whole knowledge of the field in my course. Students are also a good help when needed.

20) The amount of input given by field specialist is very low. The amount of input provided by the language instructors is very high and there is a lot of modeling input.

21) Field specialists' classes are highly closed and include translation and reading activities, but language classes are very diverse and have many interactive patterns in the classroom.

22) Language teachers have a lot of skill in adapting and adjusting their language level with the students. Field specialist are not familiar with this important matter, therefore in some cases their expectations can be very high or very low.

23) Language teachers are more familiar with the built-in syllabus.

24) The amount of material taught in the language teacher's classroom is much higher than that of a field specialist.

25) Exams designed by language teachers are more professional and organized than those designed by field specialists.

26) In my opinion, the course I had with a field specialist was not constructive at all, and I did not learn much.

27) The experience I had with a language teacher, my English improved from various dimensions. My goal in such courses is to improve my speaking, writing and reading skills.

28) My purpose of attending this class is to enhance my general English including writing and listening skills, and many other things that I can learn from a language teacher. The last thing I expect from my language teacher is knowing a few specific words in the field.

29) In my opinion, if language teachers teach an ESP course for years, they will have a great deal of background knowledge and teach well in that field.

30) In my opinion, the classes of field specialists are devoid of motivation. It is because they are not interested in teaching these courses and see it as an unavoidable compulsory task in their academic life.

Note: The participants' answers were collected using a four-point Likert-scale from strongly agree to strongly disagree. 